\title{
PROFINET IPARI PROTOKOLL ALKALMAZÁSA ELEKTROPNEUMATIKUSAN TÁVMÚKÖDTETETT FÚVÓS HANGSZEREN
}

\section{APPLYING PROFINET INDUSTRIAL PROTOCOL FOR A RECORDER CONTROL BY ELECTROPNEUMATICS SYSTEM}

\author{
Liptai Tibor István1, Tóth János2 \\ ${ }^{I}$ Debreceni Egyetem Müszaki Kar, Villamosmérnöki és Mechatronikai Tanszék, \\ 4028, Magyarország, Debrecen, Ótemetö utca 2-4., tibor.liptai@gmail.com \\ ${ }^{2}$ Debreceni Egyetem Müszaki Kar, Villamosmérnöki és Mechatronikai Tanszék, \\ 4028, Magyarország, Debrecen, Ótemetö utca 2-4., tothjanos@eng.unideb.hu
}

\begin{abstract}
Nowadays, the industrial communication networks are the one of the most important research area in advance control systems. It is necessary to think about controlling tasks at system level instead of local solutions. There are different types of protocols developed for communication between industrial controlling devices. In our study we are introducing an application of PROFINET communication protocol for a recorder which is vocalized by an electropneumatic system. The main goal of the developed model is to create the communication between controlling devices which are far away from each other.

Keywords: PROFINET, controlling, webserver, electropneumatic system, recorder.

\section{Összefoglalás}

Napjainkban az ipari kommunikációs protokollok nagy fejlődési potenciállal rendelkező terület a fejlett vezérlési és irányítási rendszerek kapcsán. Szükséges az irányítási feladatokra nem csak lokális szinten koncentrálni. Az ipari eszközök egymás közötti kommunikációjára többféle, egymástól eltérő protokoll lett kifejlesztve. Tanulmányunkban a PROFINET kommunikációs protokoll alkalmazását mutatjuk be egy elektropneumatikus rendszer segítségével müködtetett fúvós hangszeren. A létrehozott modell fő célja, hogy több, térben különböző helyen elhelyezkedő ipari eszköz kommunikációját megvalósítsuk.
\end{abstract}

Kulcsszavak: PROFINET, irányitás, webszerver, elektropneumatikus rendszer, furulya.

\section{Bevezető}

Tanulmányunkban egy fúvós hangszer megszólaltatását kívánjuk megvalósítani ipari eszközök segítségével, ahol a beavatkozást elektropneumatikus eszközök hajtják végre, míg az irányítási, vezérlési és távfelügyeleti feladatokat Phoenix Contact PLC-k látják el. A PLC-k egymás közötti kommunikációja egy modern ipari protokoll, a PROFINET-en keresztül valósul meg.

\section{A furulya irányítása}

A furulyát irányító és megszólaltató elektropneumatikus rendszer vezérlését Phoenix Contact eszközökkel valósítottuk meg. Annak érdekében, hogy több, külön- 
böző eszköz közötti kommunikációt megvalósítsuk és bemutassuk, nemcsak az elektropneumatikus rész lett két részre választva, hanem a teljes, furulyát müködtető vezérlő rendszer is.

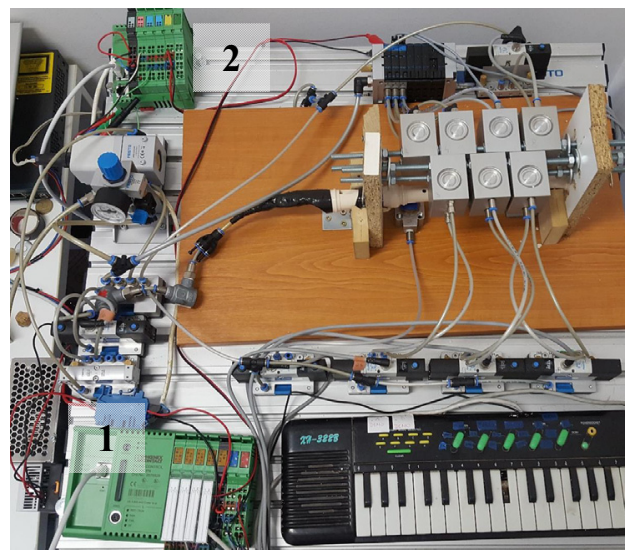

1. ábra. Az elektropneumatikus furulya szerkezeti felépitése

A rendszer fö vezérlő egysége az ILC 350 PN típusú, Phoenix Contact által gyártott PLC (1). A furulya vezérléséhez, irányításához és távfelügyeletéhez szükséges programkód ezen az eszközön fut, illetve hajtódik végre, és ez innen irányítja a többi, hálózathoz csatolt eszközt is. Az eszköz közvetlenül vezérli a furulya lyukainak lefogását végző pneumatikus munkahengereket.

Az IL PN BK PROFINET eszköz (2) térben az ILC 350 PN vezérlőtől távol helyezkedik el. A vezérlő feladata a furulyatestbe jutó levegő előkészítése. Az eszköz szabályozza a levegő nyomását, és az analóg nyomásszabályozó szelep segítségével befolyásolja a levegőmennyiséget a furulyáig vezetö úton.

$\mathrm{Az}$ irányítást végző eszközök között a PROFINET nyílt ipari, Ethernet hálózaton alapuló kommunikációs szabvány teremt kapcsolatot. Működési sebessége elérheti a $100 \mathrm{Mbit} / \mathrm{s}-\mathrm{t}$, amelyet csavart érpár vagy optikai kábel segítségével valósít meg.
A kommunikáció képes együttmüködni már meglévő terepi buszrendszerekkel is, például a Phoenic Contact által is alkalmazott INTERBUS terepi kommunikációval. A PROFINET kommunikáció két nagy csoportra bontható, valós idejű kommunikációra, illetve olyan alkalmazásokra, ahol nem szükséges a valós idejü támogatás.

A valós idejü alkalmazásokat olyan helyeken használják, ahol fontos a megbízható, minél rövidebb válaszidő betartása. $\mathrm{Az}$ igények itt is különbözőek lehetnek. A gyártásban résztvevő eszközök körülbelül $10 \mathrm{~ms}$ válaszidőt, ezzel szemben a robotmozgások vezérlése (Motion control) már 1 ms válaszidőt igényelnek. A PROFINET ipari kommunikációs szabvány képes kiszolgálni ezeket az elvárásokat a Real-Time csatornán [3] [4].

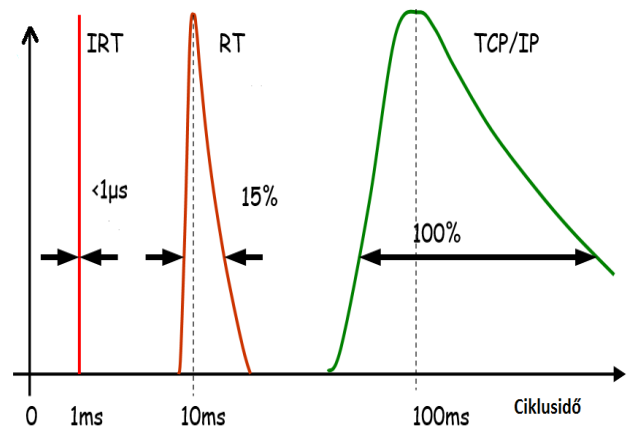

2. ábra. Ciklus- és válaszidők a PROFINET különbözö típusainál

\section{Az elektropneumatikus kapcso- lás}

A furulya működtetését végrehajtó rendszer elektropneumatikus elemekből lett megvalósítva. Ahhoz, hogy az ipari kommunikáció előnyeit minél jobban be tudjuk mutatni, a furulya müködéséért felelős részegységeket elkülönítettük, és térben egymástól távol helyeztük el. A müködés két nagy csoportra lett osztva:

- Fújási levegő előkészítése;

- Furulyán található hangok lefogása. 


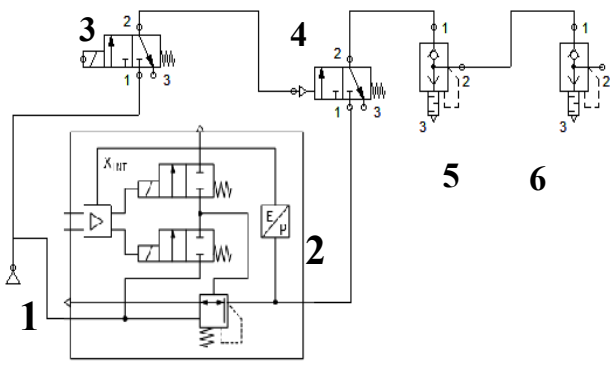

3. ábra. Fújási levegöt elöállító pneumatikus elektropneumatikus kapcsolás

A fújási levegő előállító elektropneumatikus részegység felépítése:

- Pneumatikus tápegység (3. ábra, 1.);

- Arányos, elektropneumatikus Festo VPPE-3-1/8-6-10 típusú nyomásszabályozó szelep,

(3. ábra, 2.);

- Festo elektromos vezérlésü, 3/2-es, monostabil, rugó-visszatérítéses, pneumatikus útváltó szelep

(3. ábra, 3.);

- Festo pneumatikus vezérlésü, 3/2-es, monostabil, rugó-visszatérítéses, pneumatikus útváltó szelep

(3. ábra, 4.);

- Festo gyorsleürítő szelep

\section{(3. ábra, 5-6.).}

A pneumatikus tápegységből a levegő közvetlenül az elektropneumatikus, arányos nyomásszabályozó szelepbe érkezik. Ezen szelep feladata, hogy a beérkezö levegö nyomását megváltoztassa annak a függvényében, hogy éppen melyik hangot kívánjuk müködtetni a furulyán. A szelep elektromos vezérlésü, analóg jellel lehet befolyásolni a kimeneti nyomásértéket.

A nyomásszabályzó kimenetén kilépő szabályozott nyomással rendelkező levegőmennyiség ezután elindul a furulya felé. Kezdetek során innen közvetlenül a furulyába jutott a levegőmennyiség, de több probléma adódott a megvalósítással.
- Az analóg nyomásszabályozó szelep be,- és kikapcsolási karakterisztikája miatt a hangok nem egyből szólaltak meg a furulyán, hanem több fals hangon keresztül „kapcsolt be” a kívánt hang;

- A nyomásszabályozó szelep és a furulya közötti csőszakaszban, a hang vezérlöjel megszünése után is maradt levegőmenynyiség, amely nem kívánt, elnyújtott hangot eredményezett.

A nem kívánt hangok megszüntetésére a kapcsolást több útváltó szeleppel is kiegészítettük. Ezen szelepek alkalmazásával ki lett küszöbölve az arányos nyomásszabályozó szelep be-, és kikapcsolási karakterisztikája, a kívánt hang egyből megszólal a furulyán.

A nyomásszabályozó szelep és a furulya közötti csővezetékben és szelepekben a hangvezérlö jel megszünése utáni visszamaradó levegőmennyiség, és ennek hatására létrejövő elnyúló hang megoldásaként a furulyatest elé gyorsleürítő szelepet helyeztünk. A várt eredményt két gyorsleürítő szelep együttes alkalmazása hozta meg $(5,6$.$) .$

A furulyán lévő lyukak lefogásáért felelős elektropneumatikus részegység 3/2-es monostabil útváltó szelepekből és kettős müködésű munkahengerekböl áll. Mindegyik lyuk lefogását egy-egy munkahenger végzi. [2]

\section{A webszerver bemutatása}

$\mathrm{Az}$ elektropneumatikus furulya webszerver segítségével irányítható, illetve látható el a hozzá kapcsolódó távfelügyelet. A müködtetésre alapvetően két mód áll rendelkezésre, manuális mód, illetve elöre beállított dallam lejátszása.

A webszerveren keresztül, egyetlen Ethernet kábel segítségével elérhető a furulyához tartozó összes általunk programozott funkció. A webszerver müködéséhez nincs szükség külön alkalmazásra, egyszerüen egy átlagos böngészőből futtatható, ameny- 
nyiben a böngésző ki van egészítve JAVA bővítménnyel.

A manuális módban lehetőség van a fizikai billentyüzettel dallamot lejátszani, vagy pedig a webszerveren elérhető manuális mód részen a megfelelő hangot szimbolizáló billentyüre kattintva megszólaltatni a hangokat. Amennyiben valamelyik hang megszólaltatásra kerül, az a webszerver hangskáláján azonnal láthatóvá válik. Az éppen aktív hang jelölése színben tér el a többi hangtól, a 4. ábrán látható.

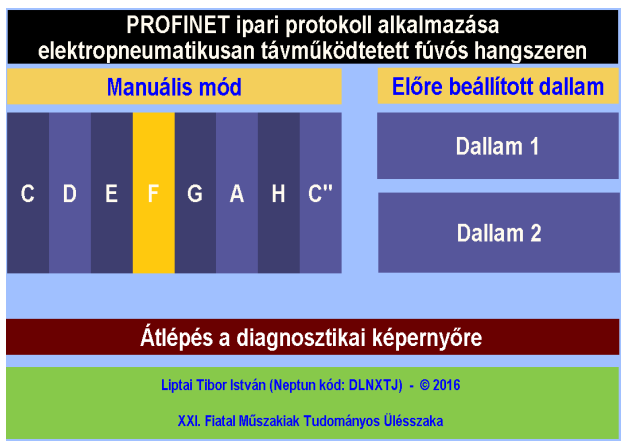

4. ábra. Webszerver kezdőképernyője

A PROFINET ipari kommunikációs hálózat segítségével nem csak webszerveren keresztül megvalósított irányítás lehetséges, hanem élő adatok lekérdezhetősége válik lehetővé. Az élő, furulyát érintő adatokhoz a diagnosztikai képernyőre kell váltani.

A PROFINET protokoll további elönye, hogy fejlett diagnosztikai rendszerrel rendelkezik. A fejlesztői környezetben láthatóak mind a PROFINET eszközök, mind a PROFINET hálózatát jellemző állapotok, hiba esetén pedig a hiba jellege is nyomon követhető.

Természetesen nemcsak a fejlesztői környezetben érhetőek el az állapotjelzők, hanem a webszerveren is megtekinthetőek. Nemcsak állapotjelzők érhetőek el a webszerver segítségével, de a hálózatra csatlakoztatott eszközök száma is megjeleníthető. Az elektropneumatikus furulyát irányító PROFINET hálózat a következő információkat jeleníti meg a webszerveren keresztül:

\begin{tabular}{|r|r|}
\hline \multicolumn{2}{|c|}{ DIAGNOSZTIKAI KÉPERNYŐ } \\
\hline \multicolumn{2}{|c|}{ PLC állapotjelzők } \\
\hline Standby $O$ ONLINE & Leállítva \\
\hline PROFINET állapotjelzők \\
\hline Csatlakoztatott eszközök & PROFINET aktív \\
\hline Hiba a hálózaton & Szükséges eszköz \\
\hline Kommunikáció mûködik & nincs csatlakoztatva \\
\hline Diagnosztikai figyelmeztetés & \\
\hline
\end{tabular}

5. ábra. Webszerver diagnosztikai képernyője

\section{Következtetések}

Munkánk során kialakítottunk egy elektropneumatikus szerkezetet, amely egy furulyát szólaltat meg. A rendszer irányítását PROFINET ipari protokoll segítségével végeztük.

Létrehoztunk egy két részből álló elektropneumatikus rendszer. Kísérleteink összegzését felhasználtuk a rendszer létrehozásánál annak érdekében, hogy csak a kívánt hangok szólaljanak meg a furulyán.

Ezután sikerrel valósítottuk meg a PROFINET hálózat kiépítését, valamint az elektropneumatikus rendszer távfelügyeletét.

\section{Szakirodalmi hivatkozások}

[1] Ajtonyi István: Ipari kommunikációs rendszerek I.AUT-INFO Kft. Miskolc, 2008. 240.-412.o

[2] Robert H. Bishop: The Mechatronics Handbook, CRC Press, USA, 2002. 4-20. fejezet

[3] Peter Neumann, Axel Pöschmann: Ethernetbased Real-Time Communication with PROFINET IO, Institut für Automation und Kommunikation Magdeburg

[4] Overview and Applications of PROFINET, Andy Verwer Verwer Training \& Consultancy Ltd, 2010 October http://www.profibus.com/

Letöltve: 2015. november 12. 